\title{
FREKUENSI PENGGUNAAN BAHASA JEPANG MAHASISWA PROGRAM STUDI PENDIDIKAN BAHASA JEPANG UNDIKSHA
}

\author{
I.P.A.W. Pradiptya ${ }^{1}$, I. W. Sadyana ${ }^{2}$, G. S. Hermawan ${ }^{3}$ \\ ${ }^{123}$ Jurusan Pendidikan Bahasa Jepang, Universitas Pendidikan Ganesha, Singaraja \\ e-mail: andhika.wedha.pradiptya@undiksha.ac.id, wayan.sadyana@undiksha.ac.id, \\ satya.hermawan@undiksha.ac.id
}

\begin{abstract}
Abstrak
Penelitian ini bertujuan untuk mengetahui frekuensi penggunaan bahasa Jepang mahasiswa Program Studi Pendidikan Bahasa Jepang Undiksha dan apa penyebab tinggi rendahnya tingkat frekuensi tersebut. Pendekatan yang digunakan dalam penelitian ini yaitu pendekatan kuantitatif dan kualitatif dengan menggunakan metode penelitian deskriptif. Populasi dalam penelitian ini yaitu mahasiswa Program Studi Pendidikan Bahasa Jepang Undiksha angkatan 2016, 2017, 2018 dengan menggunakan teknik random sampling untuk penelitian kuantitatif dan purposive sampling untuk penelitian kualitatif. Jumlah sampel dalam penelitian kuantitatif yaitu 30 orang dan penelitian kualitatif berjumlah 9 orang. Berdasarkan hasil analisis data didapatkan bahwa frekuensi penggunaan bahasa Jepang pada mahasiswa Program Studi Pendidikan Bahasa Jepang Undiksha masih tergolong rendah, dimana rata-rata aspek reseptif $54,44 \%$ dan produktif $57,00 \%$. Faktor penyebabnya adalah kurangnya kemampuan penguasaan kosakata, tata bahasa Jepang, dan fasilitas penunjang belajar.
\end{abstract}

Kata kunci: faktor penyebab, frekuensi, penggunaan bahasa Jepang

\section{要旨}

本研究はガネシャ教育大学の日本語教育学科の学生の日本語使用頻度とその頻度の 高低の原因を調べることを目的としている。本研究では記述的研究手法を用いた定 量的と定性的なアプローチを用いる。本研究では定量的研究のためにランダムサン プリング技術と定性的研究のために目的サンプリング技術を採用した日本語教育学 科の世代2016年、2017年、2018年の学生を対象している。定量的研究のサンプル数 は 30 人と定性的研究は 9 人である。データ分析の結果から、平均的な受信が $57,00 \%$ 発信が54, 44\%と比較的低いというカテゴリーと明らかになった。その要因として は語彙、文法、学習支援設備の不足である。

キーワード：要因、頻度、日本語使用

\section{Pendahuluan}

Universitas Pendidikan Ganesha merupakan salah satu universitas yang menyelenggarakan program studi Pendidikan Bahasa Jepang dengan tujuan menghasilkan sarjana yang terdiri dari tenaga kependidikan bahasa Jepang, pengkaji bahasa Jepang, tenaga ahli pariwisata bahasa Jepang, dan penerjemah bahasa Jepang. Untuk mencapai tujuan tersebut perlu memperhatikan penguasaan Bahasa Jepang secara teori maupun praktek.

Dalam menguasai bahasa Jepang sama halnya dengan menguasai bahasa asing lainnya, menurut Nurgiyantoro (2001:270) terdapat empat aspek kemampuan berbahasa yaitu kemampuan menulis (書く能力), kemampuan menyimak (聞く能力), kemampuan membaca (読む能力), dan kemampuan berbicara (話す能力). Keempat kemampuan berbahasa tersebut dapat digolongkan menjadi dua aspek, yaitu aspek reseptif dan aspek produktif. Aspek reseptif disebut pemahaman informasi yang diterima atau jushin (受信), dapat diartikan pula sebagai proses usaha memahami simbol-simbol bahasa yang dituturkan oleh orang lain, meliputi kemampuan menyimak dan kemampuan membaca. Aspek produktif atau aspek penggunaan, dalam bahasa Jepang disebut hasshin (発信), terdiri dari kemampuan berbicara dan kemampuan menulis. 
Dari kedua aspek tersebut bahasa dalam kehidupan manusia merupakan suatu elemen penting yang memungkinkan proses komunikasi berlangsung salah satunya bahasa Jepang. Sapani, (1997) mengemukakan bahwa kegiatan berbahasa pada dasarnya ialah kegiatan berkomunikasi. Oleh karena itu, belajar bahasa pada hakikatnya sama dengan belajar berkomunikasi. Dengan demikian tujuan umum belajar bahasa asing termasuk bahasa Jepang adalah mencapai kemampuan berkomuikasi (communicate), terutama kemampuan menyampaikan pikiran kepada orang lain serta dapat menguasai bahasa Jepang secara produktif dan reseptif.

Penelitian mengenai frekuensi penggunaan bahasa Jepang mahasiswa program studi pendidikan Bahasa Jepang pernah dilakukan oleh Mersili (2015) yang meniliti tingkat frekuensi penggunaan bahasa Jepang pada mahasiswa dan mengetahui penyebab tingkat frekuensi penggunaan bahasa Jepang pada mahasiswa di Universitas Negeri Semarang. Pada penilitian ini untuk mengetahui frekuensi penggunaan bahasa Jepang menggunakan sub variabel faktor psikologis dan sosial. Sedangkan untuk mengetahui faktor yang mempengaruhi penggunaan bahasa Jepang menggunakan sub variabel faktor internal dan eksternal. Pengumpulan data penelitian ini menggunakan angket dan wawancara terstruktur. Pendekatan yang digunakan dalam penelitian ini merupakan pendekatan kuantitatif dan kualitatif dengan menggunakan metode penelitian deskriptif. Penelitian ini menggunakan tekhnik Random Sampling. Jumlah sampel dalam penelitian kuantitatif adalah 60 orang dan untuk penelitian kualitatif berjumlah 18 orang.

Berdasarkan hasil analisis data Mersili (2015) didapatkan bahwa frekuensi penggunaan bahasa Jepang pada mahasiswa Prodi Pendidikan Bahasa Jepang Unnes masih tergolong rendah. Dengan rata-rata reseptif $63,08 \%$ dan produktif $59,50 \%$. Untuk faktor penyebabnya ialah kurangnya kemampuan penguasaan kosakata maupun tata bahasa Jepang dan kurangnya faslititas yang belajar yang menunjang.

Penelitian frekuensi penggunaan bahasa Jepang mahasiswa program studi pendidikan Bahasa Jepang Undiksha menarik untuk dilakukan penelitian. karena sebelumnya, belum ada penelitian mengenai pendekatan kuantitatif di program studi pendidikan bahasa Jepang Undiksha. Selain itu hasil observasi awal di dalam kelas, lima dari tujuh dosen pengampu mata kuliah bahasa Jepang untuk angkatan 2018, 2017, dan 2016 terlihat bahwa ketika dosen memberikan stimulus berbahasa Jepang, mahasiswa memberikan respon menggunakan bahasa Jepang yang tergolong rendah. Dimana respon yang digunakan sebatas hai atau ya dan iie atau tidak. Selanjutnya mahasiswa lebih cenderung merespon ketika dosen memberikan stimulus menggunakan bahasa Indonesia. Mahasiswa juga cenderung ragu-ragu untuk memberikan respon ketika dosen meminta mahasiswa untuk berusaha menggunakan bahasa Jepang. Sedangkan untuk hasil observasi awal di luar perkuliahan mahasiswa terlihat tidak menggunakan bahasa Jepang secara menyeluruh.

Penelitian Mersili (2015) alasan responden memilih jawaban tidak dicantumkan pada angket, sehingga tidak mewakili alasan semua jawaban respon yang dipilih. Selain itu tidak ditambahkannya teori pendukung yang relevan, sehingga tidak mewakili dari hasil yang didapatkan. Sehingga penelitian ini akan dicantumkan alasan responden pada angket dengan menggunakan teknik wawancara tak terstruktur, serta mencantumkan beberapa referensi teori pendukung yang relevan. Urgensi dari penelitian ini nantinya dapat memberikan informasi dan pengetahuan mengenai tingkat frekuensi penggunaan bahasa Jepang dan faktor penyebabnya bagi mahasiswa, dosen, dan program studi pendidikan bahasa Jepang Undiksha.

\section{Metode}

Penelitian ini dirancang menggunakan pendekatan kuantitatif dan kualitatif atau pendekatan gabungan (mixed methodology). Sampel dalam penelitian kuantitatif berjumlah 10 orang pada tiap angkatan (2018, 2017 dan 2016) sehingga jumlah sampel keseluruhan yaitu 30 orang. Sampel penelitian kualitatif dipilih secara random berjumlah 3 orang tiap angkatan, sehingga jumlah sampel keseluruhan yaitu 9 orang. Metode pengumpulan data yang digunakan terdiri dari metode observasi, angket online, wawancara tidak terstruktur secara online, dan dokumentasi. Selanjutnya data hasil penelitian yang diperoleh akan dianalisis deskriptif. 


\section{Hasil dan Pembahasan}

\section{Hasil}

Hasil analisis angket rata-rata presentase aspek reseptif frekuensi penggunaan Bahasa jepang mahasiswa angkatan 2018, 2017, dan 2016 Program Studi Pendidikan Bahasa Jepang Undiksha tersaji pada tabel 1 dan aspek produktif pada tabel 2.

Tabel 1. Rata-rata presentase aspek reseptif

\begin{tabular}{|c|c|c|}
\hline Pernyataan & Rata-Rata & Kesimpulan \\
\hline Pernyataan 1 & $43,33 \%$ & Rendah \\
\hline Pernyataan 2 & $45,83 \%$ & Rendah \\
\hline Pernyataan 3 & $35 \%$ & $\begin{array}{c}\text { Sangat } \\
\text { Rendah }\end{array}$ \\
\hline Pernyataan 4 & $49,17 \%$ & Rendah \\
\hline Pernyataan 5 & $50 \%$ & Rendah \\
\hline Pernyataan 6 & $80,63 \%$ & Tinggi \\
\hline Pernyataan 7 & $63,33 \%$ & Tinggi \\
\hline Pernyataan 8 & $55,83 \%$ & Rendah \\
\hline Pernyataan 9 & $62,50 \%$ & Rendah \\
\hline Pernyataan 10 & $55,83 \%$ & Rendah \\
\hline
\end{tabular}

Berdasarkan hasil rata-rata persentase aspek reseptif bahasa Jepang didapatkan bahwa pada pernyataan 6 dan 7 termasuk dalam kategori tinggi, serta pernyataan 3 termasuk dalam kategori sangat rendah dan pernyataan aspek lainnya dikategorikan rendah. Rata-rata total persentase aspek reseptif yaitu $54,44 \%$ sehingga diketahui bahwa frekuensi penggunaan bahasa secara reseptif masih tergolong rendah.

Tabel 2. Rata-rata presentase aspek produktif

\begin{tabular}{|c|c|c|}
\hline Pernyataan & Rata-Rata & Kesimpulan \\
\hline Pernyataan 11 & $53,30 \%$ & Rendah \\
\hline Pernyataan 12 & $44,17 \%$ & Rendah \\
\hline Pernyataan 13 & $49,17 \%$ & Rendah \\
\hline Pernyataan 14 & $50 \%$ & Rendah \\
\hline Pernyataan 15 & $82,50 \%$ & $\begin{array}{c}\text { Sangat } \\
\text { Tinggi }\end{array}$ \\
\hline Pernyataan 16 & $74,17 \%$ & Tinggi \\
\hline Pernyataan 17 & $55 \%$ & Rendah \\
\hline Pernyataan 18 & $47,50 \%$ & Rendah \\
\hline Pernyataan 19 & $46,70 \%$ & Rendah \\
\hline Pernyataan 20 & $67,50 \%$ & Tinggi \\
\hline
\end{tabular}

Berdasarkan hasil rata-rata persentase aspek produktif bahasa Jepang didapatkan bahwa pada pernyataan 15 termasuk dalam kategori sangat tinggi, pernyataan 16 dan 20 termasuk dalam kategori tinggi dan pernyataan aspek lainnya dikategorikan rendah. Rata-rata total persentase aspek produktif yaitu $57,00 \%$ sehingga diketahui bahwa frekuensi penggunaan bahasa secara produktif masih tergolong rendah.

Hasil wawancara persentase kemampuan berbahasa Jepang mahasiswa program pendidikan bahasa Jepang angkatan 2016, 2017 dan 2018, Universitas Pendidikan Ganesha tersaji pada gambar grafik 1 . 


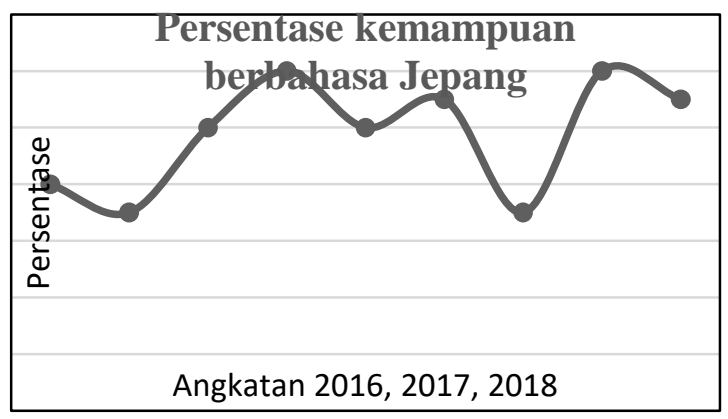

Gambar 1. Grafik Persentase Kemampuan Berbahasa Jepang

Gambar. 1 menunjukan hasil wawancara tidak terstruktur terhadap 9 orang mahasiswa mengenai faktor penyebab tinggi rendahnya frekuensi penggunaan bahasa Jepang oleh mahasiswa program studi pendidikan bahasa Jepang Undiksa. Rata-rata pesentase kemampuan penggunaan bahasa Jepang mahasiswa pendidikan bahasa Jepang yaitu $48,33 \%$ dengan rentang persentase 0\% sampai 100\%. Persentase kemampuan berbahasa Jepang ini dapat dikatakan rendah.

\section{Pembahasan}

Berdasarkan hasil angket yang dilakukan, frekuensi penggunaan bahasa Jepang pada mahasiswa tergolong rendah. Dari 20 pernyataan yang diberikan kepada responden hanya 5 pernyataan yang menunjukan frekuensi penggunaan bahasa Jepang pada mahasiswa tergolong tinggi, yaitu memberi salam kepada dosen dan teman menggunakan bahasa Jepang, menulis menggunakan hiragana dan katakana saat perkuliahan, latihan menulis kanji diluar perkuliahan, mendengarkan lagu berbahasa Jepang dan mendengarkan dan menerjemahkan langsung saat dosen mengajar menggunakan bahasa Jepang. Faktor penyebab yang terbanyak dalam rendahnya penggunaan bahasa Jepang pada mahasiswa adalah kurangnya kemampuan penguasaan kosakata maupun tata bahasa Jepang, minat membaca kurang dan kurangnya fasilitas penunjang belajar.

Hasil wawancara tidak terstruktur terhadap 9 orang mahasiswa mengenai faktor penyebab tinggi rendahnya frekuensi penggunaan bahasa Jepang oleh mahasiswa Program Studi Pendidikan Bahasa Jepang Undiksha yaitu rata-rata persentase kemampuan penggunaan bahasa Jepang mahasiswa pendidikan bahasa Jepang yaitu 48,33\%, dan tergolong rendah.

Menurut hasil wawancara aspek reseptif penyebab persentase kemampuan penggunaan bahasa Jepang rendah yaitu minat membaca bacaan bahasa Jepang kurang, jarang mendapat bacaan selain yang terdapat di buku belajar, rendahnya pengetahuan dalam kanji, kosakata sehingga tidak mampu memahami isi bacaan menyeluruh, kurangnya penyediaan bahan bacaan atau literasi berbahasa Jepang, terakhir karena terkadang kegiatan yang mendatangkan pembicara asli bahasa Jepang tidak melibatkan seluruh mahasiswa dan terkadang tidak rutin didatangkan.

Sedangkan pada hasil wawancara aspek produktif penyebab rendahnya presentase dikarenakan mahasiswa tidak berani menajawab atau berbicara dengan dosen karena kemampuan tata bahasa dan kosakata yang rendah, ditambah semakin tinggi semester, semakin jarang menggunakan bahasa Jepang. Selain itu adanya istilah sonkeigo dan kenjogo yang membuat mahasiswa bingung dalam melakukan perubahan bentuk kata kerja yang terkadang membuat kesalahan seperti meninggikan posisi diri sendiri atau merendahkan posisi orang lain. Istilah ini dimaksudkan untuk menghormati seseorang yang memiliki posisi lebih tinggi di lingkungan kampus seperti dosen ketika berkomunikasi menggunakan bahasa Jepang. Mahasiswa cenderung lebih nyaman menggunakan teineigo yang sering digunakan di dalam atau luar perkuliahan dan ditemukan di bacaan bahasa Jepang. Selain itu penggunaan teineigo tidak terikat aturan seperti sonkeigo yang meninggikan orang lain dan kenjogo yang merendahkan diri sendiri sehingga bersifat netral. Penyebab lainnya mahasiswa jarang berbicara menggunakan bahasa Jepang karena jarang 
mendengarkan dosen berbicara menggunakan bahasa Jepang hanya satu atau dua dosen saja yang berbicara bahasa Jepang. Mahasiswa lebih sering menulis dengan hiragana dan katakana, jarang menggunakan kanji karena mahasiswa jarang membaca bacaan yang banyak mengandung unsur kanji serta tidak ingat urutan penulisan untuk huruf yang jarang digunakan.

Menurut Astami (2015) pada umumnya aspek keterampilan berbahasa tersebut mengacu pada proses decoding dan encoding. Proses decoding merujuk pada proses untuk memahami tuturan orang lain baik yang lisan atau pun tulis dan disebut dengan kemampuan reseptif. Ada pun yang termasuk ke dalam keterampilan decoding, yakni menyimak dan membaca. Sementara itu, yang dimaksud dengan proses encoding adalah proses untuk menghasilkan sesuatu berupa ujaran atau pun tertulis, kemampuan ini masuk ke dalam kategori keterampilan yang bersifat produktif dan yang termasuk ke dalam keterampilan encoding, yakni berbicara dan menulis.

Pada aktivitas menyimak sangat dibutuhkan kemampuan untuk memperhatikan dan mendengarkan dengan baik apa yang diucapkan oleh orang lain dalam bentuk monolog maupun dialog. Dapat berupa siaran berita, pengumuman informasi di bandara mengenai jadwal keberangkatan, orang yang sedang bercakap-cakap di telepon dan sebagainya. Sedangkan, pada aktivitas membaca dibutuhkan akan kemampuan untuk memahami isi tulisan orang lain. Dapat berupa membaca di dalam hati ataupun dilisankan, yakni berupa ulasan berita surat kabar, iklan mengenai loker, surat dan sebagainya (Astami, 2015).

Hasil wawancara aspek produktif tersebut sesuai dengan teori Sutedi (2011:40) yang menyatakan bahwa keberhasilan seseorang mempelajari suatu bahasa asing salah satunya bahasa Jepang, akan lebih mudah dilihat dan diperhatikan oleh orang lain dari kelancaran berbicaranya. Kelancaran tersebut tidak terlepas dari unsur kebahasaan, penguasaan huruf yang dipakai, kosakata, sistem pengucapan, gramatika dan ragam bahasa dalam bahasa Jepang.

Menurut Marhiyanto (2008) berbicara merupakan suatu kegiatan berbahasa yang melahirkan ujaran dan ide untuk disampaikan (didengar) orang lain. Berbicara merupakan sebuah keterampilan yang memerlukan latihan secara terus menerus. Tanpa dilatih, seorang akan terus-menerus berdiam diri dan tidak akan berani untuk menyuarakan pendapatnya. Iskandarwassid \& Dadang Sunendar (2015:241) mengemukakan bahwa keterampilan berbicara pada hakikatnya merupakan keterampilan mereproduksi arus sistem bunyi artikulasi untuk menyampaikan kehendak, kebutuhan perasaan, dan keinginan kepada orang lain. Pengajaran keterampilan berbicara harus mampu memberikan kesempatan kepada setiap individu mencapai tujuan yang dicita-citakan.

Bila melihat proses berbicara, yang terjadi adalah ketika mengungkapkan sesuatu yang akan diutarakan tentunya berlaku proses: (1) Memikirkan apa yang hendak disampaikan. (2) Memikirkan bagaimana cara menyampaikan. (3) Baru berbicara. Tentunya apa yang ingin diutarakan dengan apa yang dapat diutarakan keduanya terjadi gap. Hal tersebut berlaku pada komunikasi dua arah (dialog), yakni komunikasi yang terjadi antara penutur dan mitra tutur (Kida, 2007).

Menurut teori Kushartanti (2005:58) apabila ingin memiliki kemampuan menguasai bahasa Jepang dan seberapa jauh penguasaan seseorang terhadap bahasa Jepang tergantung dari sering tidaknya dia menggunakan bahasa tersebut. Hal ini disebabkan karena, informasi akan tersimpan baik dalam memori manusia jika informasi diperoleh secara bertahap dan melalui penyebaran yang rata dalam satu kurun waktu. Sehingga semakin sering seseorang mendengarkan dan membaca terkait bahasa Jepang maka memori pada manusia akan tersimpan dengan baik.

Tinggi rendahnya frekuensi penggunaan bahasa Jepang dipengaruhi oleh beberapa faktor menurut Kushartanti (2005:25) dan Sujanto (1998:191) faktor-fakor yang memiliki peran besar dalam keberhasilan berkomunikasi dalam berbahasa yaitu faktor fisik, psikologis, media dan sosial. 


\section{Simpulan dan Saran}

Berdasarkan hasil dan pembahasan penelitian ini dapat disimpulkan bahwa:

(1) Kegiatan berbahasa Jepang mahasiswa Prodi Pendidikan Bahasa Jepang secara reseptif rata-rata adalah 54,44\%.Dari hasil persentase tersebut dapat diketahui bahwa kegiatan berbahasa mahasiswa secara reseptif masih tergolong rendah. Sedangkan, kegiatan berbahasa mahasiswa Prodi Pendidikan Bahasa Jepang secara produktif rata-rata adalah $57,00 \%$. Hasil tersebut menunjukan bahwa kegiatan berbahasa mahasiswa secara produktif pun masih tergolong rendah.

(2) Hasil wawancara menunjukan terdapat faktor-faktor yang mempengaruhi penggunaan bahasa Jepang pada mahasiswa, yaitu fakor internal dan faktor eksternal. Faktor internal yang dimaksud adalah keterbatasan pengetahuan kosakata dan tata bahasa Jepang, kurangnya kemampuan mahasiswa dalam penguasaan materi pembelajaran atau tidak sepenuhnya menangkap materi pembelajaran, minat mahasiswa yang rendah dalam membaca bahan bacaan atau literasi berbahasa Jepang, dan kurangnya motivasi mahasiswa dalam menggunakan bahasa Jepang karena takut melakukan kesalahan. Sedangkan, faktor eksternalnya adalah kurangnya keterlibatan dosen dalam mensosialisasikan media pembelajaran berbahasa Jepang kepada mahasiswa baik digunakan di dalam maupun luar perkuliahan, kurangnya referensi bahan bacaan, kurangnya penutur asli Jepang yang rutin didatangkan, dan kurang diikut sertakan seluruh mahasiswa dalam kegiatan jurusan yang mendatangankan pembicara bahasa Jepang.

\section{Saran}

Perlu dilakukan penelitian kuantitatif lebih lanjut, guna mendapat hasil penelitian yang lebih spesifik pada salah satu aspek bahasa Jepang sehingga dapat membantu kurikulum pembelajaran bahasa Jepang yang semakin baik. Bagi mahasiswa dapat melakukan banyak kegiatan, misalnya aktif bertanya dan menjawab saat perkuliahan berlangsung, mengulang materi pelajaran yang telah dipelajari untuk dapat menguasainya dengan baik, serta aktif mencari referensi bahan bacaan untuk dapat. Bagi pihak penyelenggara pendidikan diharapkan mampu meningkatkan sarana dan fasilitas guna menunjang proses pembelajaran bahasa Jepang serta mampu mendatangkan tenaga pendidik atau penutur asli bahasa Jepang lebih rutin dimana kegiatan yang dilaksanakan bersama mampu melibatkan seluruh mahasiswa.

\section{Ucapan Terima Kasih}

Terimakasih banyak kepada dosen pembimbing, dosen penguji, Bapak I Gusti Nyoman Yudi Hartawan, S.Si., M.Sc. selaku dosen matematika Undiksha, mahasiswa Program Studi Pendidikan Bahasa Jepang Undiksha angkatan 2018, 2017, dan 2018 yang telah membantu serta memberi dukungan atas terlaksananya penelitian ini.

\section{Daftar Pustaka}

Kushartanti, Yuwono, U., dan Lauder, R. M. T. 2005. Pesona Bahasa: Langkah Awal Memahami Linguistik. Jakarta: PT Gramedia Pustaka Utama.

Mersili, YD. 2015. "Frekuensi Penggunaan Bahasa Jepang Mahasiswa Prodi Pendidikan Bahasa Jepang Unnes". Fakultas Bahasa dan Seni. Universitas Negeri Semarang: Semarang.

Nurgiyantoro, Burhanudin. 2001. Penilaian Dalam Pengajaran Bahasa dan Sastra. Yogya: BPFE-Yogyakarta.

Sapani, Suardi et al. 1997. Teori Pembelajaran Bahasa. Jakarta: Depdibud. 
Slameto. 2010. Belajar dan Faktor-Faktor yang Mempengaruhinya. Jakarta: Rineka Cipta.

Sudjianto da Dahidi, A. 2007. Pengantar Linguistik Bahasa Jepang. Jakarta: Kesaint Blanc.

Sutedi, Dedi. 2011. Penelitian Pendidikan Bahasa Jepang. Bandung: Humaniora.

Astami, T.S. Model Pembelajaran Kaiwa Tingkat Dasar Sesuai Dengan Jf Standard. 2015. Jurnal LINGUA CULTURA. 9(2) : 94-99.

Marhiyanto, B. 2008. Pintar Bahasa Indonesia. Surabaya: Gitamedia Press.

Iskandarwassid \& Dadang Sunendar,(2015), Strategi Pembelajaran Bahasa, Bandung:Remaja Rosdakarya.

Kida, M. 2007. Japan Foundation Nihongo Kyoujuhou Shirizu 6 Hanasu koto woshieru. Japan Foundation: Tokyo. 